\title{
Growth, digestibility, and enzyme activities in the pancreas and intestines of guinea-pigs fed on raw and heated soya-bean flour*
}

\author{
BY A. HASDAI, ZAFRIRA NITSAN AND R. VOLCANI \\ Institute of Animal Science, Agricultural Research Organization, The Volcani Center, \\ Bet Dagan 50250, Israel \\ AND YEHUDITH BIRK \\ Department of Agricultural Biochemistry and Animal Nutrition, Faculty of Agriculture, \\ Hebrew University of Jerusalem, Rehovot, Israel
}

(Received 14 March 1989 - Accepted 16 June 1989)

\begin{abstract}
The nutritional effects of giving raw (RSF) or heated (HSF) soya-bean flour to young guinea-pigs were investigated in trials 1 and 2 , in which the levels of dietary protein were 120 and $190 \mathrm{~g} / \mathrm{kg}$ diet respectively. The growth rate of animals fed on RSF was lower than that of those fed on HSF. Growth retardation of guinea-pigs fed on RSF was accompanied by a lower apparent digestibility of the protein (0.49-0.53) compared with HSF (0.67-0.76) and lower food conversion efficiency. In RSF-fed animals, increasing dietary protein affected growth and food conversion efficiency negatively. The pancreas of animals fed on RSF and HSF was similar in weight but secreted less trypsin, chymotrypsin and amylase, in RFS-fed animals. It was concluded that the mechanism by which raw soya-bean negatively affects the growth rate of guinea-pigs by reducing the activity of intestinal enzymes, differs from that suggested for rats and chicks, but is similar to that of pigs and calves.
\end{abstract}

Pancreatic enzymes: Soya-bean flour: Trypsin inhibitors: Guinea-pigs

It is well established that giving raw soya-bean flour (RSF) or other legumes to rats, chicks and mice causes growth depression, pancreatic enlargement and stimulation of its secretory activity (reviewed by Liener \& Kakade, 1980). Various investigators have attributed most of these phenomena to the presence in RSF of heat-labile trypsin inhibitors (Khayambashi \& Lyman, 1966; Gertler et al. 1967; Gertler \& Nitsan, 1970). There are, however, contradictory reports regarding the effect of RSF on enzyme activities in the pancreas and intestinal chyme of experimental animals. Elevated proteolytic activity in the pancreas of chicks and rats fed on RSF compared with heated soya-bean flour (HSF) was reported by Kakade et al. (1967), Gertler \& Nitsan (1970) and Konijn et al. (1970). Amylase (EC 3.2.1.1) activity in the pancreas of rats and chicks may be either unchanged (Gertler \& Nitsan, 1970) or slightly reduced (Kakade et al. 1967; Konijn et al. 1969) by trypsininhibitor (TI)-containing diets, whereas in the mouse it is increased (Roy \& Schneeman, 1981). Lipase (EC 3.1.1.3) activity is unaffected in chicks and mice (Nitsan \& Nir, 1977; Roy \& Schneeman, 1981). In addition to the rat and chick, the hamster (Hasdai \& Liener, 1983), mouse (Roy \& Schneeman, 1981) and young, but not adult, guinea-pig (Patten et al. 1973) have demonstrated pancreatic enlargement when fed on RSF or purified TI. Naim et al. (1982) found pancreatic hypertrophy when rats were fed on diets supplemented with soya-bean flour fractions devoid of TI activity. The ingestion of diets containing RSF or TI by chicks, rats and mice caused a marked reduction in the total proteolytic activity in

* Contribution from the Agricultural Research Organization, The Volcani Center, Bet Dagan, Israel, no. $2011-E, 1987$ series 
Table 1. Composition of diets containing raw or heated soya-bean flour ( $\mathrm{g} / \mathrm{kg}$ diet)

\begin{tabular}{lrr}
\hline Ingredient & Trial 1 & Trial 2 \\
\hline Soya-bean flour, raw or heated & & \\
Barley, ground & 240 & 365 \\
Glucose & 75 & 75 \\
Cellulose & 100 & 100 \\
Maize starch & 100 & 100 \\
Soya-bean oil & 342 & 217 \\
DL-Methionine & 50 & 50 \\
Mineral mix $\dagger$ & 6 & 6 \\
Vitamin mix $\dagger$ & 60 & 60 \\
Chemical composition & 27 & 27 \\
$\quad$ Dry matter & 880 & 890 \\
Crude protein (nitrogen $\times 6.25)$ & 123 & 188 \\
Fat & 52 & 53 \\
\hline
\end{tabular}

* Dehulled, defatted 500 or $490 \mathrm{~g}$ protein $/ \mathrm{kg}$ for raw and heated soya-bean flours respectively.

$\dagger$ Formulated according to Liu et al. (1967).

the small intestine (Gertler et al. 1967; Roy \& Schneeman, 1981), probably due to the formation of non-active complexes between trypsin (EC 3.4.21.4) or chymotrypsin (EC 3.4.21.1) and the inhibitors. Although the effects of RSF and TI have been widely studied in some experimental animals, guinea-pigs have received scant attention in this regard. It is well known that the response to RSF in the diet is age-dependent (Bornstein \& Lipstein, 1963; Nitsan \& Alumot, 1964). Newborn rats or mice are able to consume only mother's milk during the first 3 weeks of age, while guinea-pigs can be separated and fed apart from their mothers on the second or third day of life, and can consume dry food containing non-milk proteins. Therefore, the effect of feeding RSF can be studied in this species from a very early age.

The object of the present work was to study the response of guinea-pigs to diets containing RSF or HSF, at two levels of dietary protein, with respect to growth, nutrient digestibility and secretory function of the pancreas.

\section{MATERIALS AND METHODS}

Two trials were conducted, using two levels of protein in the diets.

\section{Trial 1}

Sixteen 4-to-5-d-old Hartley guinea-pigs (purchased from the Animal Breeding Center, The Weizmann Institute of Science, Rehovot) were housed individually in metabolism cages throughout the $21 \mathrm{~d}$ experimental period. Two groups of eight guinea-pigs, equalized with respect to average body-weight, were fed ad lib. on diets containing $120 \mathrm{~g}$ protein $/ \mathrm{kg}$ from RSF or HSF (Table 1). Body-weights and food consumption were recorded twice weekly. Faeces were collected every morning on days 49 and 16-21. At the end of the trial all the guinea-pigs were killed by decapitation and the pancreas, liver and kidneys of each animal were removed, weighed immediately, and stored at $-20^{\circ}$. The contents of the jejunum and ileum were also immediately collected, weighed and stored at $-20^{\circ}$. Samples of food and faeces were analysed for dry matter, nitrogen, fat and ash according to the Association of Official Analytical Chemists (1975). For the determination of enzyme activities, the pancreas and the intestinal chyme were handled and assayed for trypsin, chymotrypsin and 
Table 2. Trials 1 and 2. Body-weight (BW) gain, food conversion efficiency and organ weights of guinea-pigs fed on diets containing $120 \mathrm{~g}$ protein $/ \mathrm{kg}$ (trial 1) or $190 \mathrm{~g}$ protein $/ \mathrm{kg}$ (trial 2) from raw $(R S F)$ or heated (HSF) soya-bean flour

(Mean values with their standard errors)

\begin{tabular}{|c|c|c|c|c|c|c|c|c|}
\hline & \multicolumn{4}{|c|}{ Trial 1} & \multicolumn{4}{|c|}{ Trial 2} \\
\hline & \multicolumn{2}{|c|}{ RSF } & \multicolumn{2}{|c|}{ HSF } & \multicolumn{2}{|c|}{ RSF } & \multicolumn{2}{|c|}{ HSF } \\
\hline & Mean & $\mathrm{SE}$ & Mean & $\mathbf{S E}$ & Mean & $\mathrm{SE}$ & Mean & $\mathrm{SE}$ \\
\hline Initial BW (g) & $136 \cdot 4$ & $7 \cdot 4$ & $138 \cdot 3$ & $7 \cdot 4$ & $127 \cdot 2$ & $4 \cdot 7$ & $127 \cdot 5$ & 3.9 \\
\hline Final BW (g) & $160 \cdot 5$ & $11 \cdot 4$ & $203 \cdot 8^{*}$ & $12 \cdot 3$ & $141 \cdot 3$ & 8.9 & $216 \cdot 7^{* *}$ & 8.7 \\
\hline Gain in $\mathbf{B W}(\mathrm{g})$ & $24 \cdot 1$ & $4 \cdot 6$ & $65 \cdot 4^{* *}$ & $9 \cdot 5$ & $14 \cdot 2$ & $5 \cdot 4$ & $89 \cdot 2 * *$ & $6 \cdot 2$ \\
\hline Food intake $(\mathrm{g})$ & 199 & $28 \cdot 1$ & $283^{*}$ & $18 \cdot 0$ & 118 & $5 \cdot 7$ & $210^{* *}$ & $8 \cdot 1$ \\
\hline Food conversion efficiency $\dagger$ & $8 \cdot 4$ & $0 \cdot 49$ & $4 \cdot 1 * *$ & 0.57 & $\ddagger$ & - & $2 \cdot 4$ & 0.12 \\
\hline Pancreas (g/kg BW) & $4 \cdot 0$ & 0.4 & 42 & 0.2 & 3.9 & $0 \cdot 2$ & $4 \cdot 1$ & $0 \cdot 1$ \\
\hline Liver $(\mathrm{g} / \mathrm{kg} \mathrm{BW})$ & $36 \cdot 5$ & $2 \cdot 2$ & $37 \cdot 6$ & $3 \cdot 4$ & $33 \cdot 1$ & $2 \cdot 3$ & $33 \cdot 8$ & $1 \cdot 0$ \\
\hline Kidney (g/kg BW) & $11 \cdot 2$ & 0.4 & $9 \cdot 7$ & 0.6 & $11 \cdot 1$ & $0 \cdot 3$ & $9 \cdot 9$ & 0.5 \\
\hline Blood glucose $(\mathrm{mmol} / \mathrm{l})$ & $6 \cdot 4$ & $0 \cdot 84$ & $8 \cdot 8$ & 1.61 & - & - & - & - \\
\hline Blood urea $(\mathrm{mmol} / \mathrm{l})$ & $3 \cdot 9$ & 0.38 & $3 \cdot 3$ & 0.45 & - & - & - & - \\
\hline $\mathrm{TI}(\mathrm{mg} / \mathrm{g}$ diet $)$ & $4 \cdot 40$ & & 0.42 & & $6 \cdot 60$ & & 0.55 & \\
\hline
\end{tabular}

TI, trypsin inhibitor.

Mean values were significantly different from those for RSF for each trial (by $t$ test): ${ }^{*} P<0 \cdot 05,{ }^{* *} P<0 \cdot 01$

$\uparrow$ Food intake $(\mathrm{g}) / \mathrm{BW}$ gain $(\mathrm{g})$.

$\$$ Since some of the guinea-pigs in this group lost weight during the experimental period, food conversion efficiency is not given.

amylase as described previously (Hasdai \& Liener, 1983). Samples of blood were withdrawn shortly before the animals were killed. The deproteinized plasma samples were analysed for urea by the method of Coulombe \& Favreau (1963) and for glucose by the glucose oxidase (EC 1 1.3.4) method (Hestrin \& Ben-Yonah, 1963). Trypsin inhibitors in the RSF and HSF diets were assayed according to Hamerstrand et al. (1981).

\section{Trial 2}

Fourteen 3-to 5-d-old Hartley guinea-pigs were kept as in trial 1 except that the dietary protein level was $190 \mathrm{~g} / \mathrm{kg}$ (Table 1). The experiment lasted for $15 \mathrm{~d}$, since the overall body condition of the animals fed on the RSF diet was poor and some of them were losing weight. Faeces were collected every morning on days $4-9$ and 10-15. The guinea-pigs were killed on day 16 of the trial, by the same procedure described for trial 1 . Chemical analysis of food and faeces and enzyme activities in the pancreas and intestinal chyme were also as in trial 1. Differences between treatments (Table 2) were determined for each trial by $t$ test (Snedecor \& Cochran, 1956). Digestion coefficients and enzyme activities of the two trials were analysed by the GLM procedure of SAS (Statistical Analysis System Inc., 1982).

\section{RESULTS}

Values of weight gains, food consumption and food conversion efficiency are presented in Fig. 1 and Table 2. Body-weight gain and food intake of the guinea-pigs fed on the diet containing RSF were significantly lower than those of animals fed on the diet containing HSF. In trial 1 , where the diets contained $120 \mathrm{~g}$ protein $/ \mathrm{kg}$, the average daily body-weight 




Fig. 1. Growth curves of guinea-pigs fed on diets containing $120 \mathrm{~g}$ protein $/ \mathrm{kg}$ (trial 1 ) or $190 \mathrm{~g}$ protein $/ \mathrm{kg}$ (trial 2) from raw $(-\infty)$ or heated $(\mathrm{O}-\mathrm{O})$ soya-bean flour. Values are means with their standard errors represented by vertical bars.

Table 3. Trials 1 and 2. Apparent digestibility of dry matter, protein, fat and ash in guineapigs fed on diets containing $120 \mathrm{~g}$ protein $/ \mathrm{kg}(\mathrm{LP}$, trial I) or $190 \mathrm{~g}$ protein $/ \mathrm{kg}(\mathrm{HP}$, trial 2) from raw $(R S F)$ or heated (HSF) soya-bean flour

\begin{tabular}{|c|c|c|c|c|c|c|c|}
\hline & \multicolumn{2}{|c|}{ Trial 1} & \multicolumn{2}{|c|}{ Trial 2} & \multirow[b]{2}{*}{ SEM } & \multicolumn{2}{|c|}{$\begin{array}{l}\text { Statistical significance } \\
\text { of interactions } \uparrow: P\end{array}$} \\
\hline & RSF & HSF & RSF & HSF & & RSF $v$. HSF & LP v. HP \\
\hline & \multicolumn{2}{|c|}{ Days 4-9 } & \multicolumn{2}{|c|}{ Days $4-9$} & & & \\
\hline Dry matter & $0.807^{\mathrm{h}}$ & $0.825^{\text {ab }}$ & $0.809^{b}$ & $0.853^{\mathrm{a}}$ & 0.011 & $<0.01$ & NS \\
\hline Protein & $0.492^{\circ}$ & $0.671^{\mathrm{b}}$ & $0.534^{\circ}$ & $0.746^{\mathrm{e}}$ & 0.021 & $<0.01$ & $<0.01$ \\
\hline Fat & 0.789 & 0.807 & 0.789 & 0.824 & 0.022 & NS & NS \\
\hline \multirow[t]{2}{*}{ Ash } & $0 \cdot 717$ & 0.741 & 0.707 & 0.685 & 0.016 & NS & NS \\
\hline & \multicolumn{2}{|c|}{ Days $16-21$} & \multicolumn{2}{|c|}{ Days $10-15$} & & & \\
\hline Dry matter & $0.806^{\mathrm{b}}$ & $0.839^{a b}$ & $0.804^{\mathrm{D}}$ & $0.854^{\mathrm{a}}$ & 0.015 & $<001$ & NS \\
\hline Protein & $0 \cdot 500^{\mathrm{b}}$ & $0.702^{\mathrm{a}}$ & $0.521^{\mathrm{b}}$ & $0.758^{\mathrm{a}}$ & 0.032 & $<0.01$ & NS \\
\hline Fat & $0.772^{\mathrm{ab}}$ & $0.822^{\mathrm{a}}$ & $0.727^{\mathrm{b}}$ & $0.825^{\mathrm{a}}$ & 0.035 & $<0.01$ & NS \\
\hline Ash & 0.673 & 0.738 & 0.717 & 0.695 & 0.019 & NS & NS \\
\hline
\end{tabular}

NS, not significant.

$a, b, c$ Values within the same horizontal row with different superscript letters were significantly different (by twoway analysis of variance) : $P<0.05$.

$\dagger$ All the interactions between protein source and level were not significant. Period effects were not statistically significant for any variable.

$\ddagger$ Pooled sEM from analysis of variance.

gain was $3 \cdot 1$ and $1 \cdot 1 \mathrm{~g}$ for the HSF and RSF groups respectively. In trial 2 , where both diets contained $190 \mathrm{~g}$ protein $/ \mathrm{kg}$, the HSF group gained $5.9 \mathrm{~g}$, while those fed on the RSF diet gained $1.4 \mathrm{~g}$ during the first $10 \mathrm{~d}$ of the experiment, slightly better than the animals fed on the RSF low protein diet in trial 1. Later on, the growth rate of some of the RSF animals 


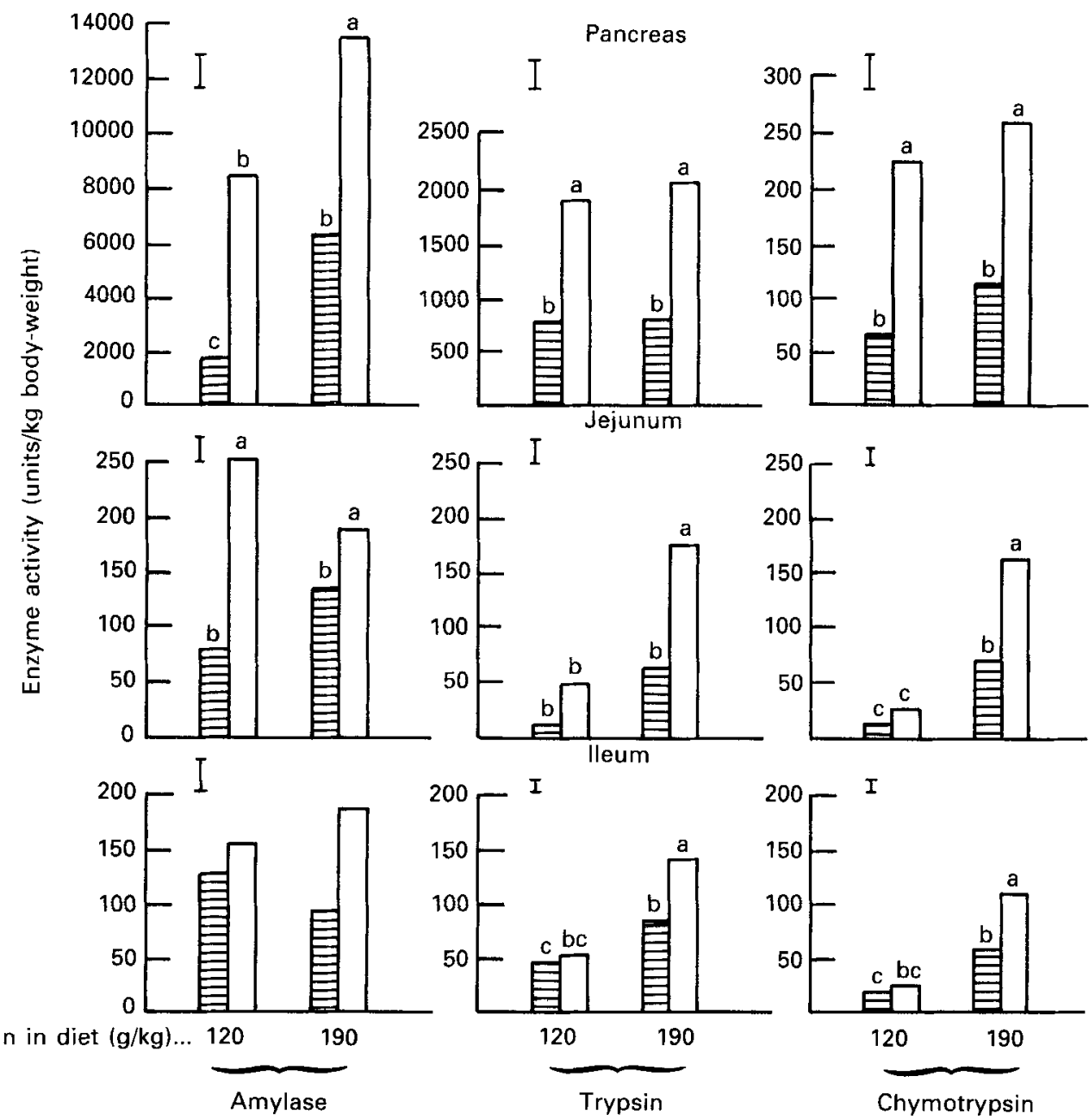

Fig. 2. The activity of amylase (EC 3.2.1.1), trypsin (EC 3.4.21.4) and chymotrypsin (EC 3.4.21 .1) (units/kg body-weight) in the pancreas, jejunum and ileum of guinea-pigs fed on diets containing $120 \mathrm{or} 190 \mathrm{~g}$ protein $/ \mathrm{kg}$ from raw $(\Theta)$ or heated $(\square)$ soya-bean flour. Values are means with their standard errors represented by vertical bars.

a. b.c Values within a site and enzyme, with different letters are significantly different $(P<0-05)$.

declined and some animals even lost weight. Food conversion efficiency (food intake/weight gain) in the HSF group was twice that of animals in the RSF group. Increasing dietary protein level improved food conversion efficiency in the group fed on HSF and markedly reduced it in the group fed on RSF. The relative weight ( $\mathrm{g} / \mathrm{kg}$ body-weight) of the pancreas and liver was similar in the HSF and RSF groups (Table 2). The relative kidney weights were 15 and $12 \%$ higher in the RSF groups than in the HSF groups in trials 1 and 2 respectively.

The apparent digestibility of dry matter was higher $(P<0.01)$ in the HSF groups than in the RSF groups, while protein content of the diet had no effect (Table 3 ). The apparent digestibility of the protein of HSF was significantly $(P<0.01)$ higher than that of RSF in both trials. Increasing the protein level in the diets improved the apparent digestibility more 
Table 4. Effect of giving raw (RSF) or heated (HSF) soya-bean flour at $120 \mathrm{~g}(\mathrm{LP})$ or $190 \mathrm{~g}$ $(H P)$ protein $/ \mathrm{kg}$ diet, on amylase (EC 3.2.1.1), trypsin (EC 3.4.21.4) and chymotrypsin (EC 3.4.21.1) activities in the pancreas and small intestine of guinea-pigs

\begin{tabular}{|c|c|c|c|}
\hline & $\begin{array}{l}\text { Protein source } \\
\text { RSF v. HSF (1) }\end{array}$ & $\begin{array}{l}\text { Protein level } \\
\text { LP } v \text {. HP (2) }\end{array}$ & $\begin{array}{l}\text { Interaction } \\
\quad(1 \times 2)\end{array}$ \\
\hline \multicolumn{4}{|l|}{ Pancreas } \\
\hline Amylase & $* *$ & $* *$ & NS \\
\hline Trypsin & ** & NS & NS \\
\hline Chymotrypsin & $* *$ & NS & NS \\
\hline \multicolumn{4}{|l|}{ Jejunum } \\
\hline Amylase & ** & NS & ** \\
\hline Trypsin & $* *$ & $* *$ & NS \\
\hline Chymotrypsin & ** & $* *$ & $* *$ \\
\hline \multicolumn{4}{|l|}{ Ileum } \\
\hline Amylase & NS & NS & NS \\
\hline Trypsin & $*$ & $* *$ & $*$ \\
\hline Chymotrypsin & NS & $* *$ & NS \\
\hline
\end{tabular}

NS, not significant.

${ }^{*} P<0.05,{ }^{* *} P<0.01$.

in the HSF group than in the RSF group, and more at an early age (4-9 d) than in the later period of the trial. The digestibility of fat was somewhat better in HSF groups than in RSF groups $(P<0.01$ at days $10-15,16-21)$.

Plasma glucose and urea levels were determined only in trial 1. Glucose level tended to be higher and urea lower in the HSF group compared with the RSF guinea-pigs, but the difference was not statistically significant (Table 2).

The activities of amylase, trypsin and chymotrypsin in the pancreas of animals fed on RSF were significantly $(P<0.01)$ lower than in their counterparts fed on the HSF diet in both trials (Fig. 2, Table 4). Increasing the protein level of the diets significantly elevated amylase activity, slightly increased chymotrypsin activity $(P>0.05)$, but had no effect on trypsin activity. Lower levels of amylase, trypsin and chymotrypsin were also found in the jejunum of guinea-pigs fed on the RSF diet, compared with those fed on the HSF diet (Table 4). These differences were statistically significant $(P<0.01)$ for amylase at both levels of protein, and for trypsin and chymotrypsin with the higher protein level only (Fig. 2). Trypsin and chymotrypsin activities were also elevated in the animals fed on the higher protein diets (Table 4). The same trend was found in the ileum as in the jejunum: trypsin and chymotrypsin activities were significantly lower $(P<0.01)$ in the RSF group than in the HSF group when fed on the high-protein diets.

\section{DISCUSSION}

The results of the present study demonstrate that young guinea-pigs are very sensitive to the growth-depressing factors of RSF. The presence of RSF in their diet significantly reduced body-weight gain, food intake and food conversion efficiency. In this respect the response of guinea-pigs to RSF was similar to that of rats and chicks. However, in rats (Nitsan \& Liener, 1976a) and chicks (Bornstein \& Lipstein, 1963) after a period of adaptation, growth rate and food conversion efficiency improve, whereas in guinea-pigs no such improvements in body-weight gain, food conversion efficiency or protein digestibility 
were noticed during the experimental period (Fig. 1). Patten et al. (1973) reported the same trend and even much more severe effects, accompanied by high mortality, in young guineapigs fed on RSF compared with those fed on casein diets. The growth rate of guinea-pigs fed on HSF rose $100 \%$ when dietary protein was increased from 120 to $190 \mathrm{~g} / \mathrm{kg}$. No such improvement was found in animals fed on RSF-containing diets. Furthermore, many of the guinea-pigs fed on the high-protein RSF diet looked sick (loss of hair, moderate diarrhoea) and started losing weight after $10 \mathrm{~d}$ on the experimental diet. This is in contrast to the response of chicks and rats, in which growth was improved when the level of RSF in the diet was increased (Gertler et al. 1967). One of the major reasons for the poor utilization of RSF by guinea-pigs would appear to be lower digestibility of the native protein in RSF $(0.49-0.53)$ compared with the heated product $(0 \cdot 67-0 \cdot 76)$, a difference which is presumably due to depression of the activities of trypsin and chymotrypsin in the intestine by the inhibitors and to the resistance of the native protein to enzymic digestion by the pancreatic proteases (Kakade et al. 1973). The digestibility of the protein in the HSF groups was slightly better during the third week compared with the first week of the experiment, while no such improvement was observed in the RSF group.

The lower level of glucose and the higher level of urea in the blood of RSF-fed guineapigs indicate that probably less energy and nitrogen were available to those animals. High negative correlations between protein quality and blood urea levels were shown for different proteins (Eggum, 1970). In contrast to what was reported for rats and chicks, no signs of enlargement were found in the pancreas of guinea-pigs fed on RSF in the present study. The relative weight of the pancreas, when expressed as a percentage of body-weight, was similar in HSF and RSF groups. Patten et al. (1973) showed that the pancreas was enlarged in young (but not in adult) guinea-pigs fed on RSF, compared with those fed on a casein diet, but this enlargement was less pronounced than that reported for rats and chicks.

The reduced digestive enzyme activities, both in the pancreas and in the small intestine (Fig. 2), indicate clearly that the pancreas of guinea-pigs fed on the RSF diet responds quite differently from that of rats, chicks and hamsters (Gertler et al. 1967; Gertler \& Nitsan 1970; Nitsan \& Liener, $1976 b$; Hasdai \& Liener, 1983). While in those species the level of free proteases in the pancreas and intestinal contents of animals fed on RSF are similar or even higher than in those fed on HSF, in spite of the fact that some of these enzymes formed inactive complexes with the inhibitors, in guinea-pigs the levels of trypsin and chymotrypsin, as well as those of amylase (Fig. 2) in the pancreas and small intestine were lower. It can, therefore, be concluded that in this species, RSF or TI cause hyposynthesis or hyposecretion of pancreatic enzymes, or both, without having any effect on the relative weight of the pancreas. It seems that the response to RSF or to TI by guinea-pig pancreas, in terms of its size and enzyme secretion, is similar to the response of pigs (Pekas, 1966), dogs (Patten et al. 1971), calves (Gorrill \& Thomas, 1967) and monkeys (Struthers et al. 1983). An increase in the dietary protein from 120 to $190 \mathrm{~g} / \mathrm{kg}$ in guinea-pigs fed on HSF, increased trypsin and chymotrypsin as well as amylase levels in the pancreas and in the small intestine, while no such response occurred in the RSF group. This is in accord with findings of Ikegami et al. (1975) who suggested that when poor-quality protein is given, the ability of the enzymes in the pancreas to adapt to the changes in dietary composition is impaired.

Patten et al. (1973) showed higher levels of pancreatic enzymes, in both young and adult guinea-pigs fed on RSF, compared with their counterparts fed on a casein diet. In this case the animals were killed $14 \mathrm{~h}$ after food removal and the high levels of pancreatic enzymes could be due to accumulation during the $14 \mathrm{~h}$ starvation period (Nitsan \& Liener, 1976 b). Gertler \& Nitsan (1970) showed that fasting for $24 \mathrm{~h}$ increased the activity of pancreatic enzymes in chicks previously fed on RSF diets, much more so than in those previously 
given HSF diets. Many authors related poor body-weight gains in rats and chicks fed on RSF to hypersecretion of the pancreatic enzymes and loss of protein and essential amino acids, mainly sulphur amino acids (for review, see Liener \& Kakade, 1980). In guinea-pigs as well as in young calves, dogs and pigs, in which hyposecretion of pancreatic enzymes was observed, a much more serious depression in body-weight gain, or even a massive loss in body-weight, occurs. It is, therefore, assumed that pancreatic enlargement and hypersecretion may contribute to overcoming the deleterious effects of RSF.

The deleterious effects of soya-bean products in sucking calves (Sissons, 1982) and piglets (Miller et al. 1984) were attributed to the presence of antigenic proteins such as glycinin and $\beta$-conglycinin. Although HSF contains large amounts of these proteins (Kilshaw \& Sissons, 1979), guinea-pigs fed on the HSF diet in the present work performed as well as those fed on the casein diet in the study of Patten et al. (1973). This may indicate that guinea-pigs are not sensitive to soya-bean antigens.

TI are believed to exert a trophic effect on the pancreas of several species, such as rats, chicks and mice, via a negative feedback mechanism, whereby a reduction in the level of trypsin in the gut causes release of cholecystokinin which stimulates the secretion of enzymes from the pancreas. Still to be investigated, however, is the mechanism whereby TI has opposite effects in guinea-pigs, pigs, calves and monkeys. Based on information from the literature, Liener (1979) has hypothesized that pancreatic enlargement will occur only in species in which pancreas relative weight $(\mathrm{g} / \mathrm{kg}$ body-weight) is greater than 3 . In the present investigation it was shown that guinea-pigs do not fit into this pattern.

\section{REFERENCES}

Association of Official Agricultural Chemists (1975). Official Methods of Analysis, 12th ed. Washington, DC: Association of Official Agricultural Chemists.

Bornstein, S. \& Lipstein, B. (1963). The influence of age of chicks on their sensitivity to raw soybean oil meal. Poultry Science 42, 61-70.

Coulombe, J. J. \& Favreau, L. (1963). A new simple semimicro method for colorimetric determination of urea. Clinical Chemistry 9, 102-108.

Eggum, B. O. (1970). Blood urea measurement as a technique for assessing protein quality. British Journal of Nutrition 24, 983-988.

Gertler, A., Birk, Y. \& Bondi, A. (1967). A comparative study of the nutritional and physiological significance of pure soybean trypsin inhibitors and of ethanol-extracted soybean meals in chicks and rats. Journal of Nutrition 91, 358-370.

Gertler, A. \& Nitsan, Z. (1970). The effect of trypsin inhibitors on pancreatopeptidase E, trypsin, chymotrypsin and amylase in the pancreas and intestinal tract of chicks receiving raw and heated soya-bean diets. British Journal of Nutrition 24, 893-904.

Gorrill, A. D. L. \& Thomas, J. W. (1967). Body weight changes, pancreas size and enzyme activity and protein digestion in intestinal contents from calves fed soybean and milk protein diets. Journal of Nutrition 92, 215-223.

Hamerstrand, G. E., Black, L. T. \& Glover, J. D. (1981). Trypsin inhibitors in soy products: modification of the standard analytical procedure. Cereal Chemistry 58, 42-45.

Hasdai, A. \& Liener, I. E. (1983). Growth, digestibility and enzymatic activities in the pancreas and intestines of hamsters fed raw and heated soy flour. Journal of Nutrition 113, 662-668.

Hestrin, L. S. \& Ben-Yonah, S. (1963). Routine determination of blood glucose with glucose oxidase. Bulletin of the Research Council of Isruel $10 \mathrm{E}, 188$.

Ikegami, S., Takai, Y.\& Iwoa, H. (1975). Effect of dietary protein on proteolytic activities in the pancreatic tissue and contents of the small intestine in rats. Journal of Nutritional Science and Vitaminology 21, $287-295$.

Kakade, M. L., Barton, T. L., Schaible, P. J. \& Evar, R. J. (1967). Biochemical changes in the pancreas of chicks fed raw soybeans and soybean meal. Poultry Science 46, 1578-1585.

Kadade, M. L., HolTa, D. E. \& Liener, I. E. (1973). Contribution of trypsin inhibitors to the deleterious effects of unheated soybeans fed to rats. Joumal of Nutrition 103, 1772-1778.

Khayambashi, H. \& Lyman, R. L. (1966). Growth deprivation and pancreatic and intestinal changes in rats force-fed amino acid diets containing soybean trypsin inhibitor. Joumal of Nutrition 89, 455-464.

Kilshaw, P. J. \& Sissons, J. W. (1979). Gastrointestinal allergy to soyabean protein in preruminant calves. Antibody production and digestive disturbances in calves fed heated soybean flour. Research in Veterinary Science 27, 361-365. 
Konijn, A. M., Birk, Y. \& Guggenheim, K. (1970). Pancreatic enzyme pattern in rats as affected by dietary soybean flour. Journal of Nutrition 100, 361-368.

Konijn, A. M., Guggenheim, K.\& Birk, Y. (1969). Amylase synthesis in pancreas of rats fed soybean flour. Journal of Nutrition 97, 265-269.

Liener, I. E. (1979). Significance for humans of biologically active factors in soybeans and other food legumes. Journal of the American Oil Chemists' Society 56, 121-129.

Licner, I. E. \& Kakade, M. L. (1980). Protease inhibitors. In Toxic Constituents of Plant Foodstuffs, pp. 7-71 [I. E. Liener, editor]. New York: Academic Press.

Liu, K. C., Typpo, J. T., Lu, J. Y. \& Briggs, G. M. (1967). Thiamine requirement of the guinea pig and the effect of salt mixtures in the diet on thiamine stability. Journal of Nutrition 93, 480-484.

Miller, B. G., Phillips, A. D., Newby, T. J., Stokes, C. R. \& Bourne, F. J. (1984). Immune hypersensitivity and post-weaning diarrhoea in the pig. Proceedings of the Nutrition Society 43, 116A.

Naim, M., Gertler, A. \& Birk, Y. (1982). The effect of dietary raw and autoclaved soya-bean protein fractions on growth, pancreatic enlargement and pancreatic enzymes in rats. British Journal of Nutrition 47, $281-288$.

Nitsan, Z. \& Alumot, E. (1964). Overcoming the inhibition of intestinal proteolytic activity caused by raw soybean in chicks of different ages. Journal of Nutrition 87, 179-184.

Nitsan, Z. \& Liener, I. E. (1976a). Studies of the digestibility and retention of nitrogen and amino acids in rats fed raw or heated soy flour. Journal of Nutrition 106, 292-299.

Nitsan, Z. \& Liener, I. E. (1976b). Enzymic activities in the pancreas, digestive tract and feces of rats fed raw or heated soy flour. Journal of Nutrition 106, 300-305.

Nitsan, Z. \& Nir, I. (1977). A comparative study of the nutritional and physiological significance of raw and heated soya beans in chicks and goslings. British Journal of Nutrition 37, 81-91.

Patten, J. R., Patten, J. A. \& Pope, H. II (1973). Sensitivity of guinea-pigs to raw soybean in the diet. Food and Cosmetics Toxicology 11, 577-583.

Patten, J. R., Richards, E. A. \& Popc, H. II. (1971). The effect of raw soybean on the pancreas of adult dogs. Proceedings of the Society for Experimental Biology and Medicine 137, 59-63.

Pekas, J. C. (1966). Zinc-65 metabolism: gastrointestinal secretion by the pig. American Journal of Physiology 211 , 407.

Roy, D. M. \& Schneeman, B. O. (1981). Effect of soy protein, casein, and trypsin inhibitor on cholesterol, bile acids and pancreatic enzymes in mice. Journal of Nutrition 111, 878-885.

Statistical Analysis System Inc. (1982). SAS User's Guide: Statistics. Cary, NC: SAS Inc.

Sisson, J.W. (1982). Effects of soya-bean products on digestive processes in the gastrointestinal tract of preruminant calves. Proceedings of the Nutrition Society 41, 53-61.

Snedecor, G. W. \& Cochran, W. G. (1956). Statistical Methods, 5th ed. Ames, Iowa: Iowa State University Press.

Struthers, B. J., MacDonald, J. R., Dahlgren, R. R. \& Hopkins, D. T. (1983). Effects on the monkey, pig and rat pancreas of soy products with varying levels of trypsin inhibitor and comparison with the administration of cholecystokinin. Journal of Nutrition 113, 86-97. 